\title{
Experimental Investigation of Low GWP Refrigerants Applied to Split Air Conditioner
}

\author{
Abdalla Gomaa $^{1}$, Fifi. N.M. Elwekeel ${ }^{1}$, Ibrahim Saber ${ }^{\mathbf{2}}$, Asmaa Khaled ${ }^{\mathbf{1}}$ \\ 1-Department of Refrigeration and Air-Conditioning Technology, \\ Faculty of Industrial Education, Helwan University. \\ 2-Department of curricula and methods of teaching, Faculty of Education, Helwan University.
}

\begin{abstract}
In this work, the thermal and environmental investigations for split air conditioner using low global warming potential (LGWP) refrigerants as alternatives to the present R22 are examined experimentally. Two alternative refrigerants of R290 $(\mathrm{GWP}=20)$ and R152a $(\mathrm{GWP}=133)$ are examined instead of R22 $(\mathrm{GWP}=1700)$. The experiments are carried out at different range of evaporator air velocities and evaporator air inlet temperatures. The experiments are conducted at evaporator air inlet temperatures of $31^{\circ} \mathrm{C}, 38^{\circ} \mathrm{C}$ and $48^{\circ} \mathrm{C}$, the air passes over evaporator coil with velocity of 0.5 to $1.6 \mathrm{~m} / \mathrm{s}$. The study parameters such as different evaporator air temperature, discharge temperature, cooling load, electrical compressor power, coefficient of performance, indirect global warming parameter and total equivalent warming parameter are investigated. The experimental results indicate that refrigerant R152a has the higher thermal performance than R22 and R290 and produces the lowest total equivalent warming parameter. At a certain evaporator air velocity is $1.2 \mathrm{~m} / \mathrm{s}$ and the evaporator air inlet temperature is $31^{\circ} \mathrm{C}$, the coefficient of performance of R152a is higher than that of R22 by $44.92 \%$. The Total Equivalent Warming Impact of R290 and R152a are lower than that of R22 by $8.2 \%$ and $30.03 \%$; respectively.
\end{abstract}

Key words: LGWP; R22 alternatives; R290; R152a; split air conditioner; COP. 


\section{NOMENCLATURE}

\begin{tabular}{|c|c|}
\hline & area $\left(\mathrm{m}^{2}\right)$ \\
\hline $\begin{array}{l}\mathrm{COP} \\
\mathrm{C}_{\mathrm{P}}\end{array}$ & $\begin{array}{l}\text { coefficient of performance (--) } \\
\text { specific heat }(\mathrm{kJ} / \mathrm{kg} . \mathrm{K})\end{array}$ \\
\hline DGWP & direct global warming potential $\left(\mathrm{kg} \mathrm{CO}_{2}\right)$ \\
\hline GWP & global warming potential $\left(\mathrm{kg} \mathrm{CO}_{2}\right)$ \\
\hline & specific enthalpy $(\mathrm{kJ} / \mathrm{kg})$ \\
\hline IGWP & indirect global warming potential $\left(\mathrm{kg} \mathrm{CO}_{2}\right)$ \\
\hline $\mathrm{L}$ & leakage factor per year $(--)$ \\
\hline$\dot{m}$ & air mass flow rate $(\mathrm{kg} / \mathrm{s})$ \\
\hline $\mathrm{n}$ & the life time of the system (Year) \\
\hline $\mathrm{P}$ & power $(\mathrm{kW})$ \\
\hline Q & heat transfer rate $(\mathrm{kW})$ \\
\hline & recycling factor of the waste refrigerant (--) \\
\hline & temperature $(\mathrm{K})$ \\
\hline & total equivalent warming impact $\left(\mathrm{kg} \mathrm{CO}_{2}\right)$ \\
\hline & velocity $(\mathrm{m} / \mathrm{s})$ \\
\hline
\end{tabular}

\section{Greek symbols}

$\beta \quad$ the $\mathrm{CO}_{2}$ emission factor for using natural gas (--)

$\rho \quad$ density $\left(\mathrm{kg} / \mathrm{m}^{3}\right)$

$\tau \quad$ Annual operating time (hr/year)

\section{Subscripts}

a air

alt alternative

comp compressor

e exit

evap evaporator

i inlet

ini initial charge of the refrigerant

\section{INTRODUCTION}

The refrigerant HCFC 22 was used in a wide range of air conditioning and refrigeration systems. When it released into the atmosphere, this leads to the depletion of the stratosphere layer. The Montreal Protocol treaty was signed in 1987 and Kyoto Protocol in 1997 to phase out the ozone-depleting refrigerants and greenhouse gases worldwide. Several studies have investigated R22 alternatives using environmentally friendly refrigerants. These studies examined the performance of vapor refrigeration system experimentally and theoretically. The primary source of the environmental problems is hydro-chlorofluorocarbons (HCFCs) refrigerants presented by Bolaji, and Huan [1]. The authors showed that the natural refrigerants such as hydrocarbons $(\mathrm{HCs})$ and their mixture are suitable for replacing HCFCs refrigerants, because the natural refrigerants have zero ODP and low GWP. Venkataiah and Rao [2] used cool pack software to compare the performance of the room air conditioning for different refrigerants and the capacity of this system was 1.5 ton. They investigated seven refrigerants with zero Ozone depletion potential as R22 alternatives. The results showed that no single refrigerant satisfied all the characteristics of R22.

Comparison of four refrigerants commonly used in vapor compression refrigeration system and Hydrofluoroolefin (HFO) refrigerants were studied by Devecioglua and Oruca [3]. The comparison was conducted according to their 
physical properties and showed that HFO refrigerants had better energy characteristics. The performance of heat pump water heating system using natural refrigerants R290 and R600a was investigated by Nawaz et al. [4]. Refrigerants R290 and R600a were used as R134a alternative. The results presented that refrigerant R290 gave better thermal performance than the base line refrigerant $\mathrm{R} 134 \mathrm{a}$, while refrigerant R600a was close to refrigerant R134a. The thermal performance of window air conditioner was investigated for mixtures of propylene and propane by Shaik and Babu [5]. The study was computed at evaporating temperature of $7.2^{\circ} \mathrm{C}$ and condensing temperature of $54.4^{\circ} \mathrm{C}$. Their results showed that the cooling capacities from all these mixtures were approach to cooling capacity of R22. The cooling capacity of the mixture R1270/R290 with concentration of ( $75 / 25$ by mass percentage) was very close to refrigerant R22 and was considered as R22 alternative in residential air conditioning. Shaik and Babu [6] investigated fifteen refrigerant mixtures from blends of HFC and HC as R22 alternatives at ARI conditions. The thermodynamic performance and COP for mixture of R134a/R1270/R290 (50/5/45 by mass percentage) were better than that for R22. COP of this mixture increased by $2.10 \%$ than that of R22.

Choudhari and Sapali [7] used parametric conditions for evaporating temperature in the range of $25^{\circ} \mathrm{C}$ to $10^{\circ} \mathrm{C}$ and constant condensing temperature of $45^{\circ} \mathrm{C}$. The natural refrigerant (R290) was used as substitution of R22 in vapor compression system. The analytical results revealed that the refrigerant mass flow rate and COP for R290 were lower than that for R22. R407C and four refrigerant mixtures of R1270, R290, RE170, R134a and R32 were investigated as R22 alternatives in residential air conditioners by Shaik and Babu [8]. The four refrigerant mixtures characterized with zero ODP and low GWP. The evaluation conducted at ARI conditions using MATLAB software. From the results, the best alternative for R22 was refrigerant mixture R134a/R1270/RE170 (55/37.5/7.5 by mass percentage) which has COP higher by $5.35 \%$ than R22. A theoretical analysis studied the performance of residential air conditioner using R22, R290 and R161 by Wu et al. [9]. R161 showed the best thermal performance than other refrigerants so it used for comparison with R22. The authors conducted another experimental study between R161 and R22.The experimental results revealed that COP of R161 increased by $4.7 \%$ and the refrigerant charge decreased by $43 \%$ compared with R22. Performances of two air conditioning systems using R22, R290, R407C and R410A were investigated by Joudi and Al-Amir [10]. The test conducted at indoor temperature of $25{ }^{\circ} \mathrm{C}$ and outdoor temperatures from $35^{\circ} \mathrm{C}$ to $55^{\circ} \mathrm{C}$. From their investigation, the results showed that R290 was the better replacement of R22 from the point of views of environmental and thermal performance. The results showed that the thermal performance of R407C was closer to R22.

Bolaji [11] tested window air conditioning system with R404A and R507 as R22 alternatives. The experiment was conducted at ambient temperature ranges from $24^{\circ} \mathrm{C}$ to $34^{\circ} \mathrm{C}$. The results showed that the $\mathrm{R} 507$ can be considered as a drop-in replacement in the current window air conditioners. This is because R507 characterized with an Ozone friendly refrigerant and had the lowest energy 
consumption compared to R22 and R404A. In vapor compression refrigeration cycle, R422D was tested as R22 alternative by Aprea, and Maiorino [12]. R422D was considered as a new refrigerant with zero ODP, but it had very high GWP. So, the authors confirmed that when R422D used in refrigeration systems, TEWI will be increased. These results were demonstrated by La Rocca and Panno [13] when they investigated the possibility of replacing R422D, R417A and R422A with R22 in vapor compression cycle. Sethi et al. [14] evaluated the HFC (R407C) and HFO (R444B) as R22 alternatives at high outdoor temperature. From simulation and experimental analysis, they concluded that the R444B presented acceptable thermal and environmental performances so it was suitable option to replace R22 in air conditioning systems. For split air conditioning device, Oruc et al. [15] performed an experimental investigation for R417A, R422A, R422D and R424 as R22 alternatives at variable ambient temperatures from $25^{\circ} \mathrm{C}$ to $41^{\circ} \mathrm{C}$. These refrigerants had zero ODP. The thermal performance of R424 was very close to thermal performance of R22 at ambient temperature of $41^{\circ} \mathrm{C}$. Antunes and Filho [16] investigated four halogenated refrigerants (R438A, R404A, R410A, R32) and two hydrocarbons refrigerants (R290, R1270) as R22 alternatives. The experiment conducted on 5 tons chiller refrigeration system at evaporating temperatures from $15{ }^{\circ} \mathrm{C}$ to $-5{ }^{\circ} \mathrm{C}$. The results showed that the hydrocarbons refrigerants (R290, R1270) achieved maximum COP and lower TEWI compared with R22.

From previous studies, it can be concluded that the many researchers have been performed energy and environmental analysis for the vapor compression refrigeration cycle using R22 alternatives, but there is still much needs to be investigated to approach the ideal refrigerant characteristics. Therefore, the objectives of the current work are to perform experimentally the thermal and environmental analysis for a split air conditioner using R290 and R152a as R22 alternatives. The proposed refrigerants will be tested, which will provide more energy efficient and lower GWP. The effects of evaporator inlet temperature, air inlet velocity and refrigerant type on the energy and environmental analysis will be investigated in the present study. Details of the tested refrigerants are listed in table1.

The alternative refrigerants under test are $\mathrm{HC}$ and $\mathrm{HFC}$. $\mathrm{HC}$ refrigerant is organic component such as the propane (R290) while R152a is HFC refrigerant, each are produced from ethane and both are considered as R22 alternative. The high GWPI produces from the greater numbers of carbon-fluorine atoms in chemical bonds while the greater number of hydrogen atoms gives a high flammable index. The refrigerants R290 and R152a are more environmentally friendly than R22 but they are less safe. Also, that is noticed in heat of combustion, R152a has high heat of combustion than that R22 but R290 has the highest value so it has an ASHRAE level A3. High normal boiling point indicates to a higher critical temperature, lower saturated pressure and therefore higher compression ratio. 
Table 1. Physical, Environmental and safety properties of R22, R152a and R290 [17]

\begin{tabular}{lccc}
\hline Physical Properties & R22 & R152a & R290 \\
\hline Molecular weight $(\mathrm{kg} / \mathrm{Kmol})$ & 86.47 & 66.00 & 44.10 \\
Normal boiling point $\left({ }^{\circ} \mathrm{C}\right)$ & -40.75 & -24.00 & -42.20 \\
Critical temperature $\left({ }^{\circ} \mathrm{C}\right)$ & 96.2 & 113.3 & 96.7 \\
Critical pressure $(\mathrm{bar})$ & 49.92 & 45.23 & 42.47 \\
Latent heat of evaporation (kJ/kg) & 233.7 & 324 & 425.4 \\
Environmental properties & & & \\
Chemical formula & $\mathrm{CHClF} 2$ & $\mathrm{CH} 3 \mathrm{CHF} 2$ & $\mathrm{C} 3 \mathrm{H} 8$ \\
Atmospheric life in years & 12 & 1.4 & 0.041 \\
Global warming potential (GWP) & 1700 & 133 & 20 \\
Ozone depletion potential (ODP) & 0.055 & 0.000 & 0.000 \\
Safety properties & & & \\
heat of combustion Mj/kg & 2.2 & 17.4 & 50.3 \\
Flammability (Safety group) & A1 & A2 & A3 \\
Lower Flammability Limit (\% volume in air) & none & 3.7 & 2.1 \\
\hline
\end{tabular}

A1: No flame, A2: Lower flammability, A3: Higher flammability

Global warming potential relative to $\mathrm{CO} 2$, (100 years' horizon)

R152a has highest normal boiling point and critical temperature, while the lowest normal boiling point is given by R290. The molecular weight of R290 and $\mathrm{R} 152 \mathrm{a}$ are lower than $\mathrm{R} 22$ by $76.3 \%$ and $51 \%$, respectively, which means that R152a and R290 have high latent heat than that of R22 in both vaporization and condensation therefore lower refrigerant mass requirement. The environmental factors of refrigerants are Ozone depletion potential (ODP), global warming potential (GWP) and atmospheric life. The refrigerant ability to destroy ozone molecules is referred to as ODP, the ODP is relative value to ODP of R-11 $(\mathrm{ODP}=1)$. The second parameter is GWP, it is indicator of the power to heat the earth planet by greenhouse gases. The average existence of refrigerant in atmosphere from releasing to decomposing means atmospheric lifetime of refrigerant. R152a and R290 are zero ODP and they have low GWP and atmospheric lifetime compared to R22. 


\section{EXPERIMENTAL TEST RIG}

The experimental system is a split air conditioner with cooling capacity of 5.25 $\mathrm{kW}$ (1.5TR) working with R22. It consists of air-cooled condenser (outdoor unit), hermetic reciprocating compressor, evaporator (indoor unit), thermostatic expansion valve and liquid receiver. The evaporator, electrical heater and axial fan are installed together in isolated galvanized steel duct as shown in Fig.1. Electrical heater was used with capacity $2 \mathrm{~kW}$ to obtain the different evaporator inlet temperatures. The experimental investigation is conducted at three evaporator inlet temperatures $31^{\circ} \mathrm{C}, 38^{\circ} \mathrm{C}$ and $48^{\circ} \mathrm{C}$. The air inlet velocity is changed to five values to change the flow rate of air over the evaporator. The condenser is placed inside isolated galvanized steel duct and electrical heater is also put in the duct to maintain the ambient temperature constant at $31^{\circ} \mathrm{C}$. For refrigerant in the system, the temperature and pressure are measured by six thermocouples and pressure gauges at different locations. Eight thermocouples are placed downstream of evaporator coil and four thermocouples installed upstream of the evaporator coil to measure the inlet air temperature and the outlet air temperature; respectively.

All thermocouples are K-type with temperature range of $\left(-200: 300{ }^{\circ} \mathrm{C}\right)$, which are connected with digital thermometer. The accuracy of thermocouples, digital thermometer and pressure gauges are $\pm 0.2 \%{ }^{\circ} \mathrm{C}, \pm 0.1 \%$ and $\pm 5 \% \mathrm{kPa}$; respectively. A digital multi meter with accuracy of $\pm 1.5 \%$ uses to measure the voltage and current for each both the compressor and the electrical heater. At different locations according to ASHRAE fundamentals [17] the air velocities are measured by hot wire anemometer with range $(0-10 \mathrm{~m} / \mathrm{s})$ and accuracy of $\pm 0.01 \%$. The recorded parameters to analysis the performance of the system, for secondary flow side are air temperatures at the evaporator inlet and exit, air flow rate in main duct, air temperature at condenser inlet and input power for electric heaters. For vapor compression refrigeration system, the measured parameters are refrigerant temperature and pressure at inlet and exit of each component as well as input electric power for compressor.

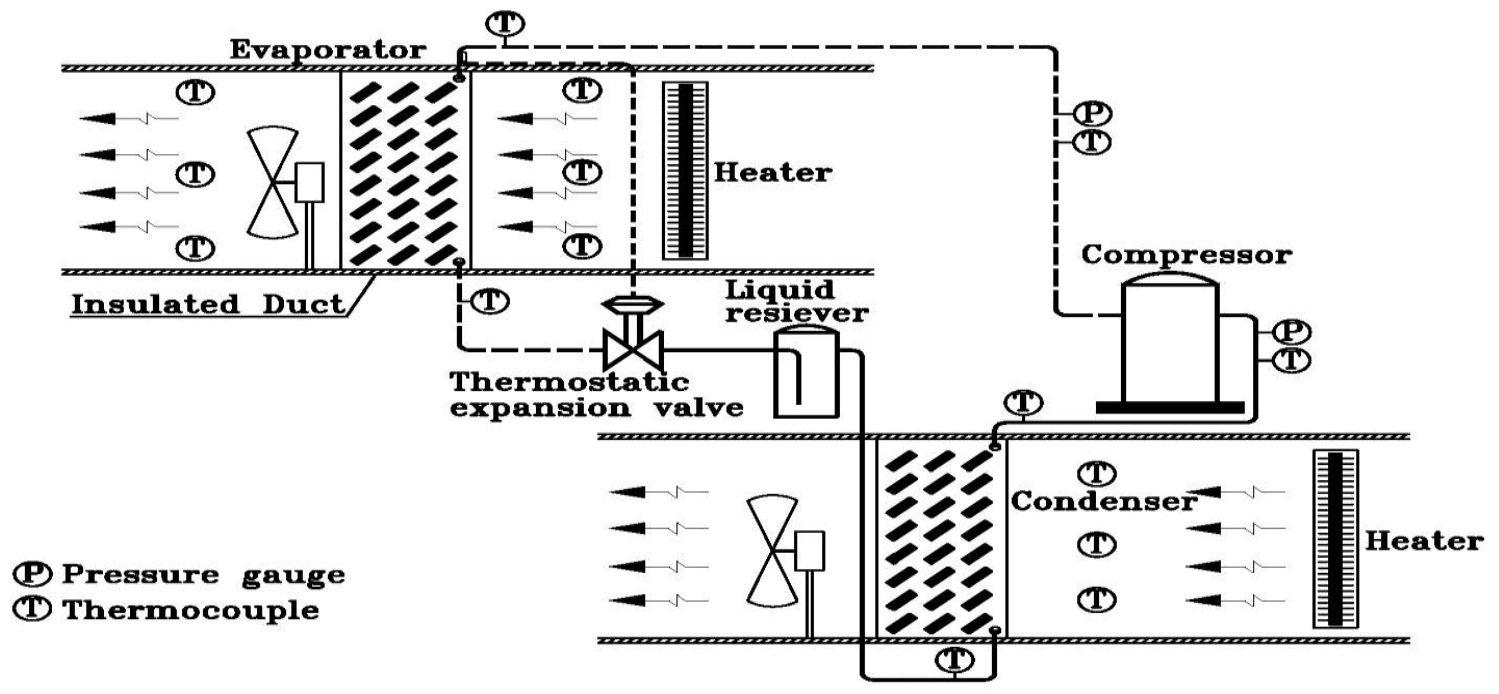

Fig. 1. Schematic diagram for the experimental test rig 


\section{DATA REDUCTION}

The governing equations for energy and environmental analyses are presented as the following:

\subsection{Thermal analysis:}

The air mass flow rate $\dot{m}_{a, e v a p}$ passes over evaporator coil can be calculated by Eq. [1]. The air density $\rho$ is calculated according to air temperature at evaporator inlet.

$$
\dot{m}_{a, \text { evap }}=\rho A V
$$

From air side the actual useful cooling capacity $Q_{\text {evap }}$ is estimated by the following equation [18];

$$
Q_{\text {evap }}=\dot{m}_{a, \text { evap }}\left(h_{\text {ai, evap }}-h_{\text {ae evap }}\right)
$$

The air density and enthalpies are calculated by EES software [19] at recorded conditions.

Actual power consumption $P_{\text {comp }}$ is determined from the measured input current, voltage and unity power factor as follows;

$$
P_{\text {comp }}=I V \cos \varphi
$$

Actual coefficient of performance $C O P$ for the system is estimated based on the measured parameters at the evaporator and compressor, i.e.

$$
C O P=\frac{Q_{\text {evap }}}{P_{\text {comp }}}
$$

\subsection{Environmental analysis:}

The Total Equivalent Warming Impact is expressed as [20]:

$$
T E W I=I G W P+D G W P
$$

Where the Indirect Global Warming Potential is calculated using the following equations;

$$
I G W P=\left(n P_{\text {comp }} \tau \beta\right)
$$

The Direct Global Warming Potential is calculated using the following equations;

$$
D G W P=\left(G W P m_{i n i}(1-r f)\right)+(G W P L n)
$$

The initial charge of R22 is $1050 \mathrm{~g}$ [21] while initial charge of R290 and R152a can be calculated by [20]:

$$
m_{\text {ini, alt }}=m_{\text {ini, } R 22}\left(\rho_{\text {alt }} / \rho_{R 22}\right)
$$


It can be noted that $\mathrm{n}, \tau, \beta, \mathrm{rf}$ and $\mathrm{L}$ are taken as 15 years, $2000 \mathrm{hr} /$ year, $0.6,0.75$ and 0.03 , respectively, $[20,22]$.

\section{UNCERTAINTY OF MEASUREMENTS}

The uncertainties in the measuring parameters and experimental results are calculated according Moffat [23]. The experimental error analysis indicates the implication of error of the measured parameters on the uncertainty of the results. The accuracy and uncertainty of instruments and measuring parameters is given in following table.

Table. 2 Experimental Accuracy and Uncertainty of measured parameters

\begin{tabular}{lcc}
\hline Measured parameters & Accuracy (\%) & Uncertainty (\%) \\
\hline air temperatures, $(\mathrm{C})$. & 0.1 & 1.72 \\
refrigerant temperature, $\left({ }^{\circ} \mathrm{C}\right)$. & 0.1 & 3.06 \\
refrigerant pressure, $(\mathrm{Psi})$. & 5 & 1.22 \\
Air velocity anemometer, $(\mathrm{m} / \mathrm{s})$. & 0.01 & 2.1 \\
\hline
\end{tabular}

\section{RESULTS AND DISCUSSION}

The effects of refrigerant type, evaporator inlet temperature and air inlet velocity on the environmental and thermal performance of split air conditioner are investigated experimentally. Refrigerant R22 is a base refrigerant and R290 and $\mathrm{R} 152 \mathrm{a}$ are alternatives refrigerant. Evaporator air inlet temperature means the temperature inlet of air flow over the evaporator, which is tested at $31^{\circ} \mathrm{C}, 38^{\circ} \mathrm{C}$ and $48^{\circ} \mathrm{C}$. The air flows over evaporator coil with velocity of 0.5 to $1.6 \mathrm{~m} / \mathrm{s}$.

\subsection{Effect of air inlet velocity:}

Figure 2 shows a comparison between the evaporator air temperature difference and evaporator air velocity for R22, R152a and R290 at different evaporator air inlet temperature. The evaporator air temperature difference decreases with increasing of evaporator air velocity. When the air flows with high velocity the air can't attached with evaporator coil so the temperature difference is high. Also, at the same evaporator air velocity the evaporator air temperature difference has a higher value at high evaporator air inlet temperature. The evaporator air temperature differences of R290 and R152a are increased than that of R22 by $5.22 \%$ and $6.09 \%$; respectively at a certain evaporator air velocity of 1.2 $\mathrm{m} / \mathrm{s}$ and evaporator air inlet temperature of $31^{\circ} \mathrm{C}$. 
The relation between cooling load of R22, R152a and R290, and evaporator air velocity at different evaporator air inlet temperature are shown in Fig. 3. The cooling load increases as evaporator inlet velocity increases. The cooling load is a function of temperature difference across evaporator coil $\left(T_{a i, \text { evap }}-T_{a e, \text { evap }}\right)$ and air mass flow rate, in this case the cooling load increases due to increasing of the air mass flow rate. Also, from Fig.3 can be seen that at the same evaporator air velocity, the cooling load is directly proportional to evaporator air inlet temperature due to increase the temperature difference across evaporator coil. The cooling load of R290 and R152a are improved than cooling load of R22 over the study range of evaporator air velocity. That is because the refrigerants R290 and R152a have high evaporator air temperature difference than that of R22 (see Fig.2). So, at a certain evaporator air velocity of $1.2 \mathrm{~m} / \mathrm{s}$ and evaporator air inlet temperature of $31{ }^{\circ} \mathrm{C}$, the cooling load of R290 and R152a are higher than that of R22 by $4.95 \%$ and $5.77 \%$; respectively.

Figure 4 presents the effect of evaporator air velocity on the electrical compressor power for R22, R152a and R290 at different evaporator air inlet temperature. It is clear that the electrical compressor power increases with increasing each of evaporator air velocity and evaporator air inlet temperature. That is because the electrical compressor power is more sensitive to increase the evaporator pressure than the reduction of the pressure ratio. Also, the highest electrical compressor power can be done by R22 while the R152a has a lowest electrical compressor power. Because the refrigerant R152a has less pressure ratio compared to the others two. The electrical compressor power for R152a decreases than that for R22 by about $26.62 \%$, for R290 it is decreased by $3.45 \%$ than that for $\mathrm{R} 22$, at a certain evaporator air velocity of $1.2 \mathrm{~m} / \mathrm{s}$ and the evaporator air temperature of $31{ }^{\circ} \mathrm{C}$. That is due to the large specific volume for R152a and followed by R290 than R22 so when use R152a, the compressor presses less amount of refrigerant mass flow rate and consumes less power.

Figure 5 shows the coefficient of performance for R22, R152a and R290 as a function of evaporator air velocity and evaporator air inlet temperature. For the three refrigerants, the coefficient of performance increases with increasing of evaporator air velocity and evaporator air inlet temperature. At a certain evaporator air velocity of $1.2 \mathrm{~m} / \mathrm{s}$ and the evaporator air inlet temperature of $31^{\circ} \mathrm{C}$, the refrigerants R290 and R152a have a higher coefficient of performance than R22 by $8.9 \%$ and 44.92\%; respectively. According to Eq. [4] there two parameters affect on trend of COP, the cooling capacity has high effect on COP than electrical compressor power. 


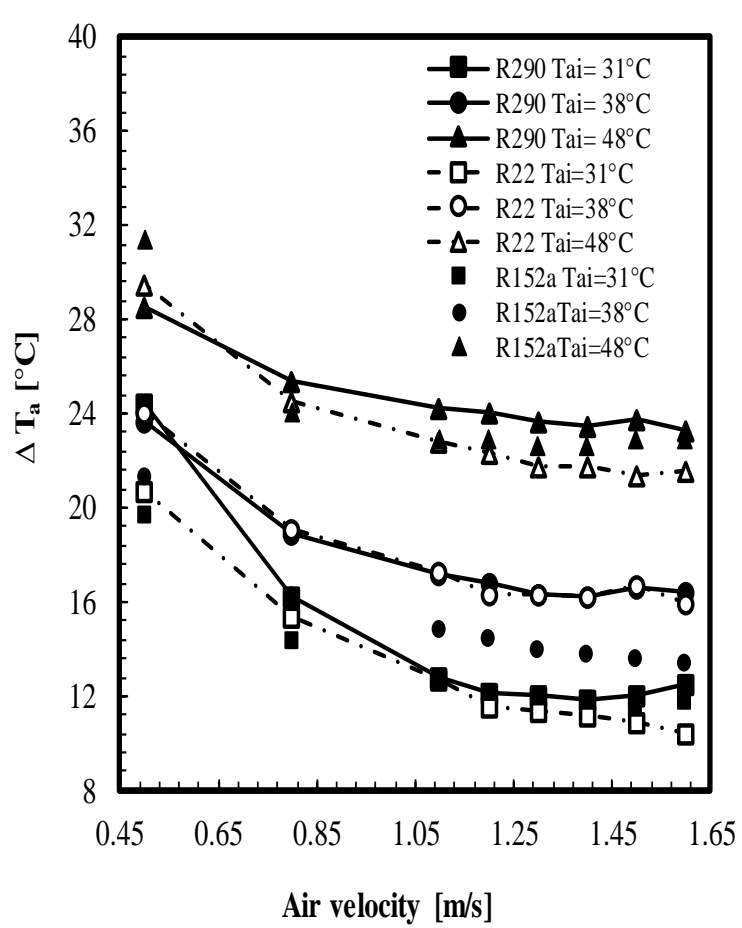

Fig. 2. Evaporator air temperature difference versus evaporator air velocity

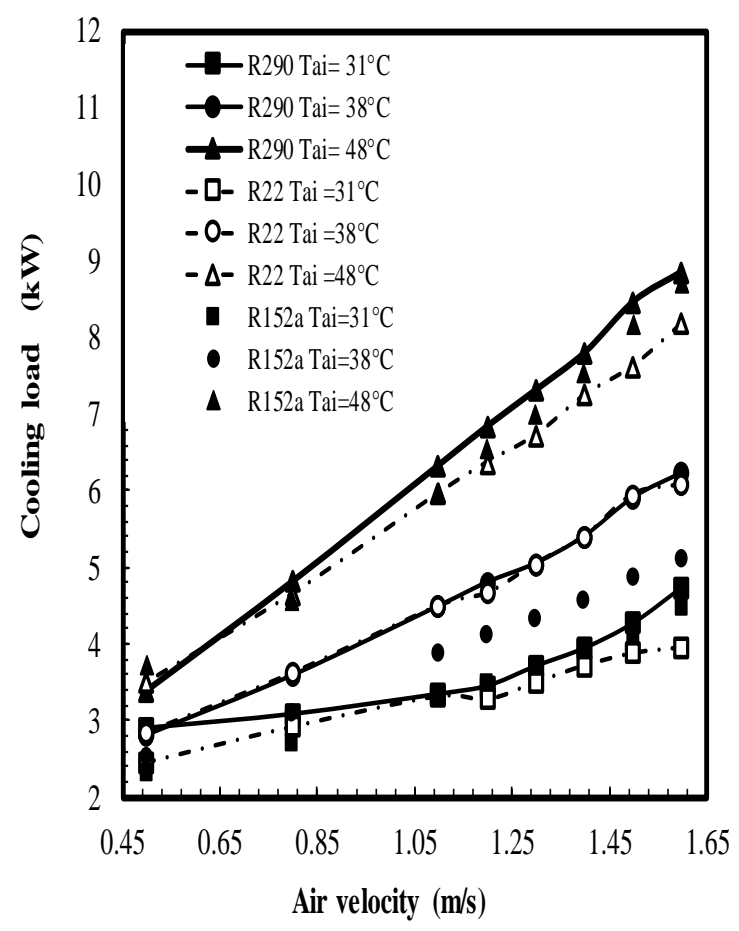

Fig. 3. Evaporator cooling load versus evaporator air velocity

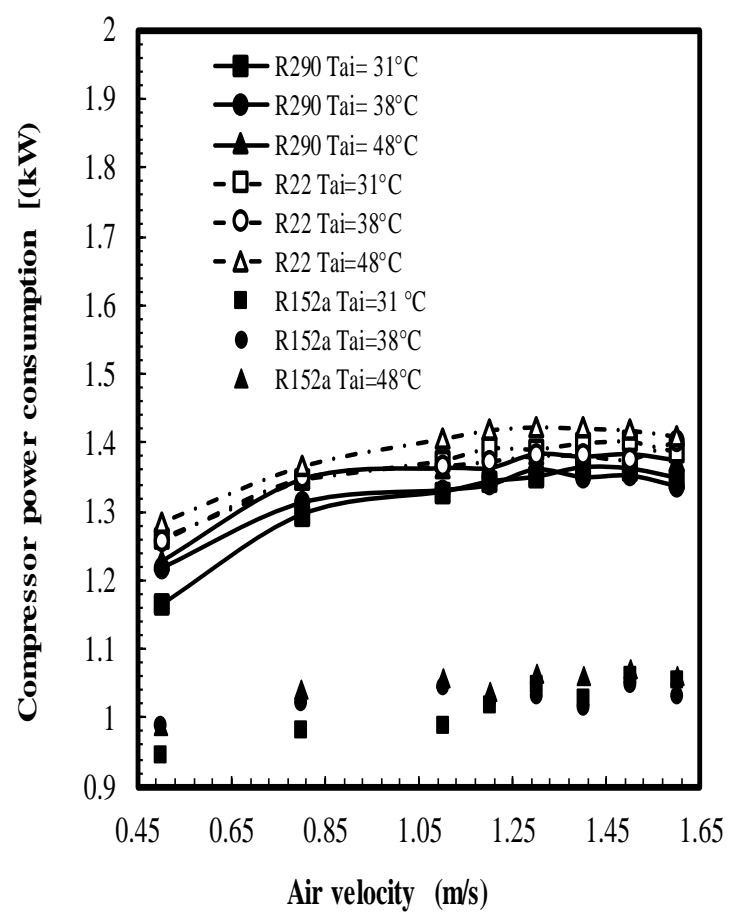

Fig. 4. Compressor power consumption versus evaporator air velocity

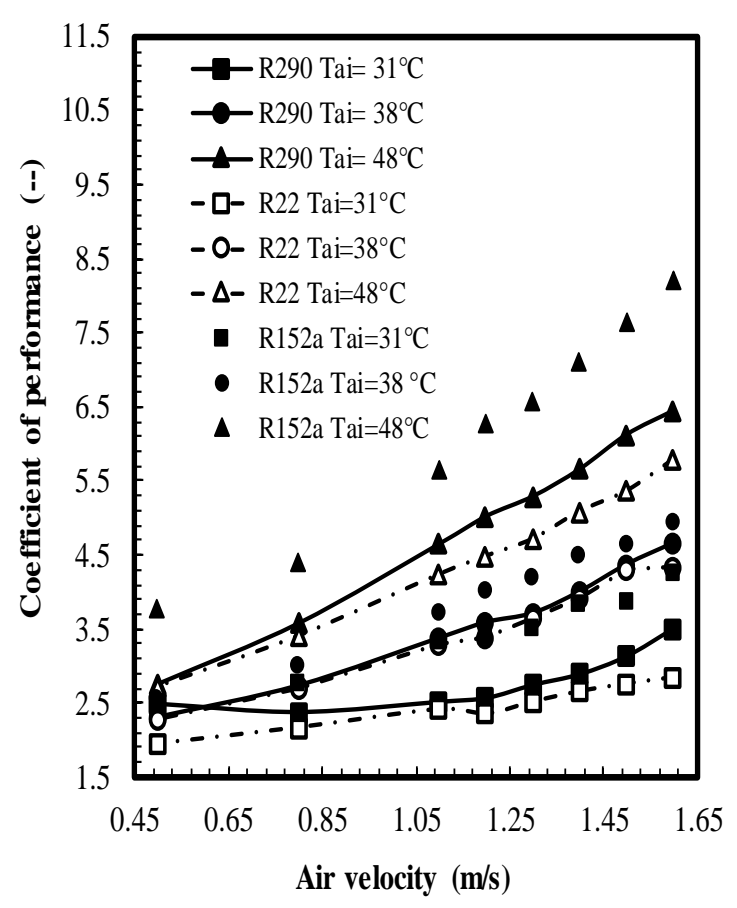

Fig. 5. Coefficient of performance versus evaporator air velocity 
This section presents the effects of evaporator air velocity at different evaporator air inlet temperature on the indirect global warming potential (IGWP) and total equivalent warming impact (TEWI) using R22, R290 and R152a.

Figure 6 illustrates the relation between IGWP and evaporator air velocity at different evaporator air inlet temperature. As expected, the indirect global warming potential (IGWP) is directly proportional with evaporator air velocity and evaporator air inlet temperature because it is depended on electrical compressor power trend (see Fig.4). So, the indirect global warming potential of R290 and $\mathrm{R} 152 \mathrm{a}$ are lower than of $\mathrm{R} 22$ by $3.58 \%$ and $26.8 \%$, respectively, at a certain evaporator air velocity of $1.2 \mathrm{~m} / \mathrm{s}$ and evaporator air inlet temperature of $31^{\circ} \mathrm{C}$.

The total equivalent warming impact for investigated refrigerants versus evaporator air velocity at different evaporator air inlet temperature is presented in Fig. 7. For studied refrigerants, the evaporator air velocity and evaporator air inlet temperature have a positive effect on TEWI. The TEWI has the same trend of IGWP therefore the total equivalent warming impact of R290 and R152a are lower than of R22 by $8.2 \%$ and $30.03 \%$, respectively when evaporator air velocity of 1.2 $\mathrm{m} / \mathrm{s}$ and evaporator air inlet temperature of $31^{\circ} \mathrm{C}$.

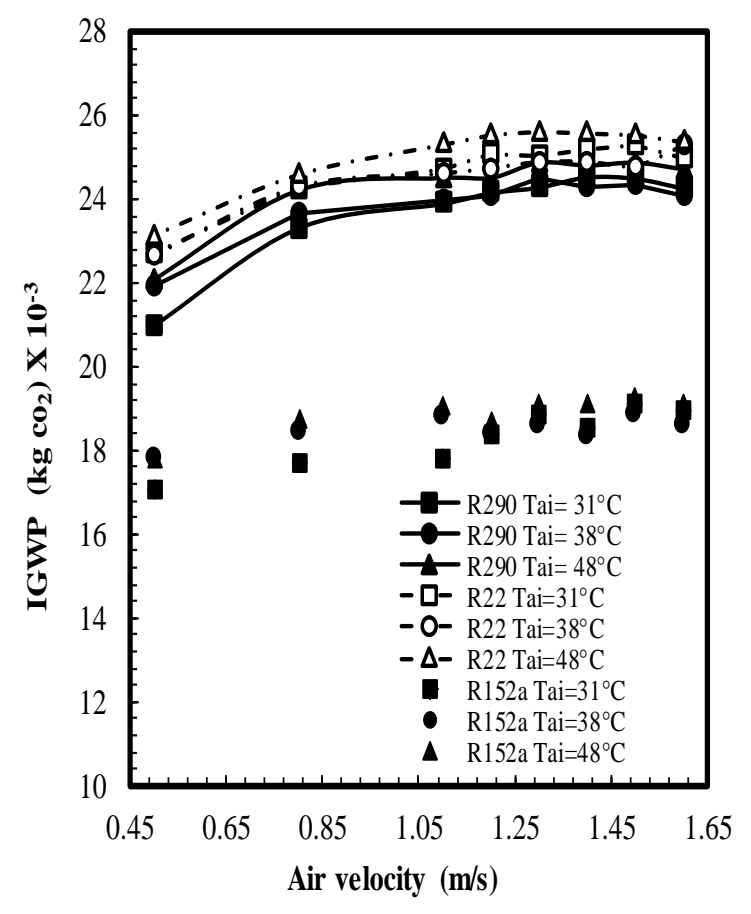

Fig. 6. Indirect global warming potential versus evaporator air velocity

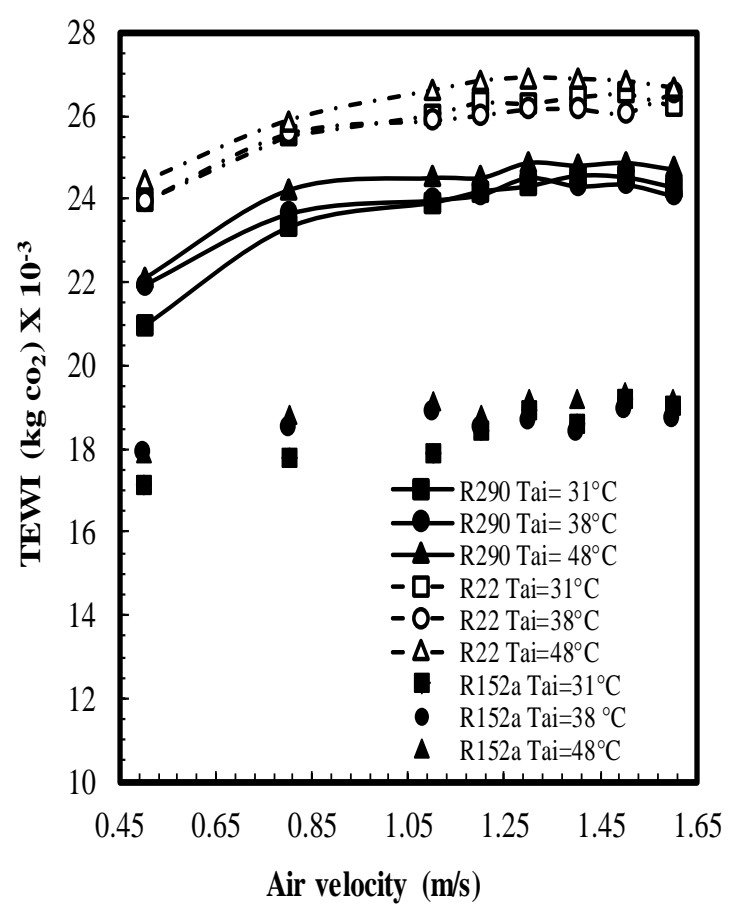

Fig. 7. Total equivalent warming impact versus evaporator air velocity 


\subsection{Effect of air inlet temperature:}

Figure 8 shows the discharge temperature as a function of evaporator air inlet temperature at different evaporator air velocity for studied refrigerants. The discharge temperature slightly decreases with increasing of evaporator air inlet temperature and evaporator air velocity. That is due to the low rate of heat transfer between airflow and the refrigerant at higher air velocity. The lowest and highest discharge temperatures are achieved by $\mathrm{R} 152 \mathrm{a}$ and $\mathrm{R} 22$, respectively. R152a has highest specific heat compared to R22 and R290 therefore it has lowest discharge temperature. The discharge temperature of R290 and R152a are lower than that for R22 by $18.62 \%$ and $59.16 \%$; respectively at a certain evaporator air velocity of 1.3 $\mathrm{m} / \mathrm{s}$ and evaporator air temperature of $38^{\circ} \mathrm{C}$. So, using R152a increases compressor lifetime compared with R22.

Figure 9 illustrates the relation between electrical compressor power and evaporator air inlet temperature for R22, R152a and R290 at different evaporator air velocity. The electrical compressor power for R290 and R152a lower than that for R22 by $1.45 \%$ and $25.36 \%$; respectively at a certain evaporator air velocity of 1.3 $\mathrm{m} / \mathrm{s}$ and the evaporator air temperature of $38^{\circ} \mathrm{C}$.

Figure 10 shows the relation between IGWP and evaporator air inlet temperature for R22, R152a and R290 at different evaporator air velocity. the indirect global warming potential of R290 and R152a are lower than of R22 by 7.85 $\%$ and $29.9 \%$, respectively, at a certain evaporator air velocity of $1.3 \mathrm{~m} / \mathrm{s}$ and evaporator air inlet temperature of $38^{\circ} \mathrm{C}$.

Figure 11 illustrates the relation between the total equivalent warming impact and evaporator air inlet temperature for investigated refrigerants at different evaporator air velocity. at a certain evaporator air velocity of $1.3 \mathrm{~m} / \mathrm{s}$ and evaporator air inlet temperature of $38^{\circ} \mathrm{C}$, the total equivalent warming impact of $\mathrm{R} 290$ and R152a are lower than of R22 by $1.49 \%$ and $25.4 \%$, respectively. 


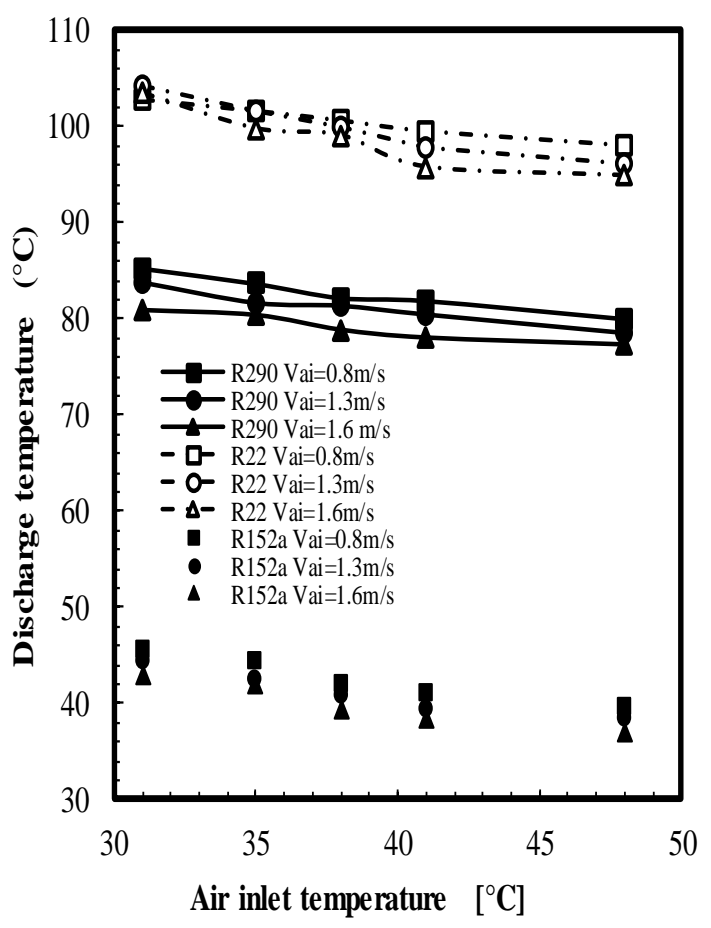

Fig. 8. Discharge temperature versus evaporator air inlet temperature

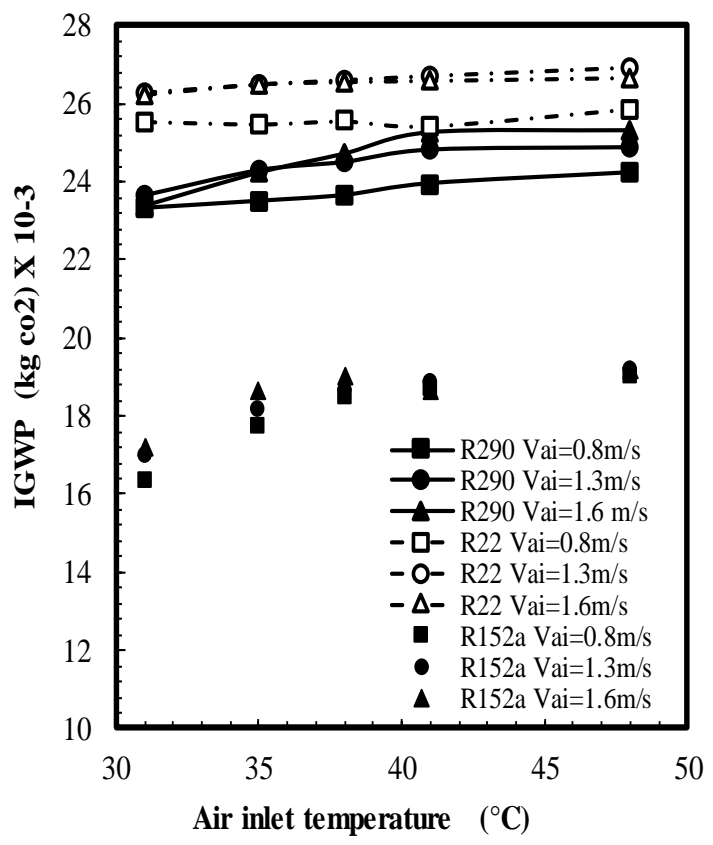

Fig. 10. Indirect global warming potential versus evaporator air inlet temperature

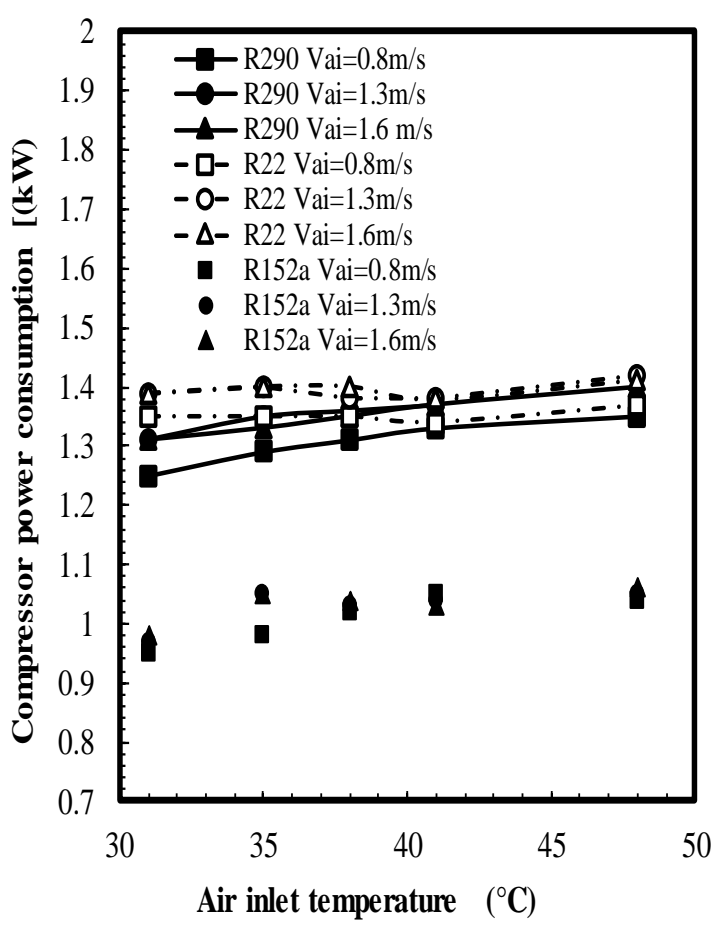

Fig. 9. Compressor power consumption versus evaporator air inlet temperature

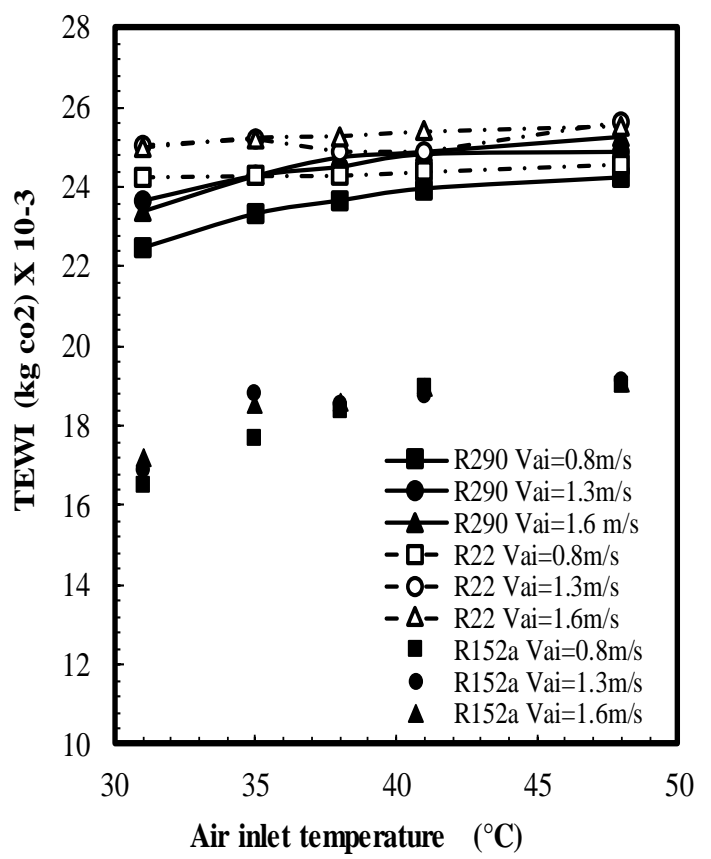

Fig. 11. Total equivalent warming impact versus evaporator air inlet temperature 


\section{CONCLUSION}

The thermal and environmental investigations for split air conditioner using R290 and R152a as R22 alternatives are examined experimentally at different range of evaporator air velocities and evaporator air inlet temperatures. From the experimental results can be concluded the following:

- The evaporator air temperature differences of R290 and R152a are higher than that of R22 by $5.22 \%$ and $6.09 \%$; respectively at evaporator air velocity of $1.2 \mathrm{~m} / \mathrm{s}$ and evaporator air inlet temperature of $31^{\circ} \mathrm{C}$.

- When evaporator air velocity and evaporator air inlet temperature are $1.2 \mathrm{~m} / \mathrm{s}$ and of $31{ }^{\circ} \mathrm{C}, \mathrm{R} 290$ and R152a have higher cooling load than that of R22 by $4.95 \%$ and $5.77 \%$; respectively.

- The electrical compressor power is directly proportional to evaporator air velocity and temperature. At a certain evaporator air velocity of $1.2 \mathrm{~m} / \mathrm{s}$ and the evaporator air temperature of $31^{\circ} \mathrm{C}$, the electrical compressor power for $\mathrm{R} 290$ and R152a are lower than that R22 by $3.45 \%$ and $26.62 \%$; respectively.

- COP increases when using R290 and R152a as R22 alternatives by $8.9 \%$ and $44.92 \%$; respectively. At a certain evaporator air velocity of $1.2 \mathrm{~m} / \mathrm{s}$ and the evaporator air inlet temperature of $31^{\circ} \mathrm{C}$.

- The compressor lifetime increases using R152a compared with R22. Whereas R152a has lowest discharge temperature, at a certain evaporator air velocity of $1.3 \mathrm{~m} / \mathrm{s}$ and evaporator air temperature of $38^{\circ} \mathrm{C}$. The discharge temperature of R152a is lower than R22 by $59.16 \%$.

- R152a presents best environmental performance than R290 and R22; which has lowest TEWI in a different range of the evaporator air velocities and the evaporator air inlet temperatures. The TEWI of R152a deceases by $30.03 \%$ than R22 at evaporator air velocity of $1.2 \mathrm{~m} / \mathrm{s}$ and evaporator air inlet temperature of $31^{\circ} \mathrm{C}$.

\section{References}

[1] B.O. Bolaji, and Z.Huan, " Ozone depletion and global warming: Case for the use of natural refrigerant - a review " Renewable and Sustainable Energy Reviews, Vol. 18, (2013), pp. 49-54.

[2] S. Venkataiah, and G. Venkata Rao, "Analysis of Alternative Refrigerants to R22 for Air-Conditioning Applications at Various Evaporating Temperatures " International Journal of Engineering Research and Applications, Vol. 86, (2014), pp. 39-46.

[3] Atilla Gencer Devecioglua, and Vedat Oruca, " Characteristics of Some New Generation Refrigerants with Low GWP" Energy Procedia, Vol. 75, (2015), pp. 1452-1457. 
[4] Kashif Nawaz, Bo Shen, Ahmed Elatar, Van Baxter, and Omar Abdelaziz, " R290 (propane) and R600a (isobutane) as natural refrigerants for residential heat pump water heaters" Applied Thermal Engineering, Vol. 127, (2017), pp. 870-883.

[5] Sharmas Vali Shaik and T.P. Ashok Babu," Thermodynamic Performance Analysis of Eco friendly Refrigerant Mixtures to Replace R22 Used in Air Conditioning Applications " Energy Procedia, Vol. 109, (2017), pp. 56-63.

[6] Sharmas Vali Shaik and T.P. Ashok Babu, "Theoretical Performance Investigation of Vapour Compression Refrigeration System Using HFC and HC Refrigerant Mixtures as Alternatives to Replace R22" Energy Procedia, Vol. 109, (2017), pp. 235-242.

[7] C.S. Choudhari and S.N. Sapali, "Performance Investigation of Natural Refrigerant R290 as a Substitute to R22 in Refrigeration Systems" Energy Procedia, Vol. 109, (2017), pp. 346 - 352.

[8] Sharmas Vali Shaik and T.P. Ashok Babu, "Theoretical Computation of Performance of Sustainable Energy Efficient R22 Alternatives for Residential Air Conditioner" Energy Procedia, Vol. 138, (2017), pp. 710-716.

[9] Yingwen Wu, Xiangfei Liang, Xiaoping Tu and Rong Zhuang, "Study of R161 Refrigerant for Residential Air-conditioning Applications". International Refrigeration and Air Conditioning Conference. (2012), pp. 1-8.

[10] Khalid A. Joudi, Qusay R. Al-Amir "Experimental Assessment of residential split type air-conditioning systems using alternative refrigerants to R-22 at high ambient temperatures" Energy Conversion and Management, Vol. 86 (2014), pp. 496-506.

[11] Bukola Olalekan Bolaji, "Performance investigation of ozone-friendly R404A and R507 refrigerants as alternatives to R22 in a window air-conditioner" Energy and Buildings, Vol. 43, (2011), pp. 3139-3143.

[12] Ciro Aprea, and Angelo Maiorino, "An experimental investigation of the global environmental impact of the R22retrofit with R422D" Energy, Vol. 36, (2011), pp. 1161-1170.

[13] Vincenzo La Rocca, and Giuseppe Panno, "Experimental performance evaluation of a vapour compression refrigerating plant when replacing R22 with alternative refrigerants" Applied Energy, Vol. 88, (2011), pp. 2809-2815.

[14] Ankit Sethi, Elizabet Vera Becerra, Samuel F. Yana Motta, and Mark W. Spatz, " Low GWP R22 replacement for air conditioning in high ambient conditions " International journal of Refrigeration, Vol. 57, (2015), pp. 26-34.

[15] Vedat Oruc, Atilla G. Devecioglu, Ugur Berk, and Ibrahim Vural, " Experimental comparison of the energy parameters of HFCs used as alternatives toHCFC-22 in split type air conditioners" International Journal of refrigeration, Vol. 63, (2016), pp. 125-132.

[16]Arthur Heleno Pontes Antunes, and Enio Pedone Bandarra Filho, "Experimental investigation on the performance and global environmental impact of a refrigeration system retrofitted with alternative refrigerants" International Journal of refrigeration, Vol. 70, (2016), pp. 119-127. 
[17] ASHRAE Handbook of Fundamentals, SI edition, Chapter 29, ASHRAE Inc., Atlanta, GA, USA, 2013.

[18] M. Fatouh, Talaat A. Ibrahim, and A. Mostafa, "Performance assessment of a direct expansion air conditioner working with R407C as an R22 alternative" Applied Thermal Engineering, Vol. 30, (2010), pp. 127-133.

[19] EES "Engineering Equation Solver", (2010), Version 6.688, F-Chart Software, WI, USA.

[20] Yitai, M., Zhao, Y., and Lu, M., "Evaluation of greenhouse warming impact for refrigerants using TEWI", Proceeding of IIF-IIR Conference, Shanghai, China, (2000), pp. 563-566.

[21] TRANE catalog, "Mini-Split Systems Hi-Wall Type" SS-PRC015-EN, (2003).

[22] Tecumseh, "Hermetic compressor service Handbook", Tecumseh products company, North America, (2011).

[23] Moffat, R. J., "Describing Uncertainties in Experimental Results" Experimental Thermal Fluid Science, 1, (1988), pp. 3-17. 